\title{
CORRECTION NOTICE
}

CORRIGENDUM: ANAEROBIC BACTERIA ISOLATED FROM CLINICAL SPECIMENS IN A UNIVERSITY HOSPITAL AND RESISTANCE OF ANAEROBIC GRAM-NEGATIVE RODS TO ANTIBIOTICS

HATA BILDIRIMI: BIR ÜNIVERSITE HASTANESINDE KLINIK ÖRNEKLERDEN IZOLE EDILEN ANAEROP BAKTERILER VE ANAEROP GRAM-NEGATIF ÇOMAKLARIN ANTIBIYOTIKLERE DIRENCI

DOI: 10.26650/IUITFD.2019.0074

Lütfiye ÖKSÜZ1

${ }^{1}$ Istanbul University, Istanbul Faculty of Medicine, Department of Medical Microbiology, Istanbul, Turkey

ORCID ID: 0000-0002-6722-141X

Oksuz L. Anaerobic bacteria isolated from clinical specimens in a university hospital and resistance of anaerobic Gram-negative rods to antibiotics. J Ist Faculty Med 2020;83(4):397-406. doi: 10.26650/IUITFD.2019.0074

Unintentional mistake in the ranking of authors' names in the $23^{\text {rd }}$ reference of the article published on page 397 in the $4^{\text {th }}$ issue of the $83^{\text {rd }}$ volume of the Journal of Istanbul Faculty of Medicine 2020 was realized. It is stated that the names of the authors in the $23^{\text {rd }}$ reference should not be in the order of "Kesli R, Demir C", but "Demir C, Kesli R". The author of the published article apologizes to the readers, and authors whose names are in the wrong order for this mistake. The explanations required to eliminate the mistakes in the article are given below. The corrected article has been published.

Correct author order for the reference 23: Demir C, Kesli R. Identification of Anaerobic Gram-Negative Bacilli Isolated from Various Clinical Specimens and Determination of Antibiotic Resistance Profiles with E-Test Methods. Mikrobiyol Bul 2018;52(1):72-9

In addition;

Page 401, column 1, row 50: Not "Keşli et al.", but "Demir et al."

Page 401, column 2, row 39: Not "Keşli et al. (27)", but "Demir et al. (23)"

Page 401, column 2, row 39 and 40: Not "Gürler et al....... (11)", but "Gürler et al $(27)^{\prime \prime}$

Page 402, column 2, row 27: Not "Keşli et al.", but "Demir et al."

Page 403, column 1, row 18: Not "Keşli et al.", but "Demir et al."

Table 3, Row 14: Not "Keşli 2018", but "Demir 2018"

\section{DÜZELTME NOTU}

CORRIGENDUM: ANAEROBIC BACTERIA ISOLATED FROM CLINICAL SPECIMENS IN A UNIVERSITY HOSPITAL AND RESISTANCE OF ANAEROBIC GRAM-NEGATIVE RODS TO ANTIBIOTICS

HATA BILDIRIMI: BIR ÜNIVERSITE HASTANESINDE KLINIK ÖRNEKLERDEN IZOLE EDILEN ANAEROP BAKTERILER VE ANAEROP GRAM-NEGATIF ÇOMAKLARIN ANTIBIYOTIKLERE DIRENCI

DOI: $10.26650 /$ IUITFD.2019.0074

Lütfiye ÖKSÜZ1

${ }^{1}$ Istanbul University, Istanbul Faculty of Medicine, Department of Medical Microbiology, Istanbul, Turkey

ORCID ID: 0000-0002-6722-141X

Oksuz L. Anaerobic bacteria isolated from clinical specimens in a university hospital and resistance of anaerobic Gram-negative rods to antibiotics. J Ist Faculty Med 2020;83(4):397-406. doi: 10.26650/IUITFD.2019.0074

İstanbul Tıp Fakültesi Dergisi'nin 2020 yılı 83. cildinin 4. sayısında 397. sayfada yayınlanmış olan makalenin 23. kaynağındaki yazar isimlerinde, makalenin yazarı tarafından sehven sıralama hatası yapılmış olup, ilgili kaynakta yazar isimlerinin "Keşli R, Demir C" şeklinde değil, "Demir C, Keşli R" şeklinde olması gerektiği belirtilmektedir. Yazar sehven yapılan bu yanlışlık için okurlardan ve ilgili kaynağın yazarlarından özür dilemektedir. Makalede yer alan hatalı yazımlar aşağıda belirtilmiştir. Makalede bu hatalar giderilerek, düzeltilmiş makale versiyonu yayına alınmıştır.

Kaynak 23'de doğru yazar sıralaması: Demir C, Keşli R. Identification of Anaerobic Gram-Negative Bacilli Isolated from Various Clinical Specimens and Determination of Antibiotic Resistance Profiles with E-Test Methods. Mikrobiyol Bul 2018;52(1):72-9

Ayrica;

Sayfa 401 1. Sütun 50. Satır: "Keşli et al." yerine "Demir et al."

Sayfa 401 2. Sütun 39. Satır: "Keşli et al. (27)" yerine "Demir et al. (23)"

Sayfa 401 2. Sütun 39. ve 40. Satır: "Gürler et al....... (11)" yerine "Gürler et al........ (27)"

Sayfa 402 2. Sütun 27. Satır: "Keşli et al." yerine "Demir et al."

Sayfa 403 1. Sütun 18. Satır: "Keşli et al." yerine "Demir et al."

Tablo 3. 14. Satır: "Keşli 2018" yerine "Demir 2018" 


\title{
ANAEROBIC BACTERIA ISOLATED FROM CLINICAL SPECIMENS IN A UNIVERSITY HOSPITAL AND RESISTANCE OF ANAEROBIC GRAM-NEGATIVE RODS TO ANTIBIOTICS (Corrected)
}

\author{
BIR ÜNIVERSITE HASTANESINDE KLINIK ÖRNEKLERDEN IZOLE EDILEN ANAEROP \\ BAKTERILER VE ANAEROP GRAM-NEGATIF ÇOMAKLARIN ANTIBIYOTIKLERE DIRENCI \\ (Düzeltildi)
}

Lütfiye ÖKSÜZ1 (D)

${ }^{1}$ Istanbul University, Istanbul Faculty of Medicine, Department of Medical Microbiology, Istanbul, Turkey

ORCID IDs of the authors: L.Ö. 0000-0002-6722-141X

Cite this article as: Oksuz L. Anaerobic bacteria isolated from clinical specimens in a university hospital and resistance of anaerobic Gramnegative rods to antibiotics. J Ist Faculty Med 2020;83(4):397-406. doi: 10.26650/IUITFD.2019.0074

\begin{abstract}
Objective: Although anaerobic bacteria are normal microbiota members in humans, they can cause endogenous and exogenous infections. The empirical treatment of anaerobic infections is based on reports of susceptibility patterns reported in various studies. This study aims to identify the anaerobic bacteria isolated from clinical samples in 2018 and to determine the resistance of anaerobic Gram-negative rods to antibiotics and to compare the results obtained with the results of anaerobic Gram-negative rods isolated between 2015 and 2017 in the same unit in this study.
\end{abstract}

Material and Method: Specimens were inoculated on Schaedler Agar and Cooked Meat Broth and incubated in anaerobic conditions. Bacteria were identified by colony morphologies, conventional tests and anaerobic diagnostic discs. Antibiotic susceptibility tests were performed using the concentration gradient method and evaluated according to the criteria of CLSI.

Results: Of the 1630 clinical samples sent for anaerobic culture, $41(2.5 \%)$ anaerobic bacteria were isolated. Most of the bacteria were isolated from the Department of Gynecology and Obstetrics (29\%), Otorhinolaryngology (29\%) clinics and mostly abscess specimens (49\%). Seventy-one percent of the isolated anaerobic bacteria were Gram-negative and 29\% Gram-positive bacteria. The most frequently isolated anaerobic bacteria were Bacteroides fragilis group (24\%) and Prevotella spp (22\%). Clindamycin resistance was quite high and there was no carbapenem resistance in anaerobic Gram-negative rods, but one third of the isolates were resistant to amoxicillin+clavulanic acid.

Conclusion: It was remarkable that more than half of the isolated anaerobic Gram-negative rods, especially the B. fragilis group,

\begin{abstract}
ÖZET
Amaç: Anaerop bakteriler, insanda normal mikrobiyota üyesi olmakla birlikte endojen ve ekzojen enfeksiyonlara neden olabilmektedir. Anaerobik enfeksiyonların ampirik tedavisi, çeşitli araştırmalarda bildirilen duyarlıık paterni raporlarına dayanmaktadır. Bu çalışmada, 2018 yılında klinik örneklerden izole edilen anaerop bakterilerin tanımlanarak anaerop Gram-negatif çomakların antibiyotiklere direnç durumlarının belirlenmesi ve elde edilen sonuçların aynı birimde 2015-2017 yılları arasında izole edilen anaerop Gram-negatif çomaklara ait sonuçlarla karşılaştırılması amaçlanmıştır.
\end{abstract}

Gereç ve Yöntem: Klinik örnekler Schaedler agar ve kıymalı buyyon besiyerlerine ekilerek anaerop ortam sağlayıc ile birlikte anaerop ortamda inkübe edilmiştir. Bakteri tanımlaması koloni morfolojisi, konvansiyonel testler ve anaerop tanı diskleri ile yapılmıştır. Antibiyotik duyarlılık deneyleri, konsantrasyon gradiyent yöntemi kullanılarak gerçekleştirilmiş ve CLSI kriterlerine göre değerlendirilmiştir.

Bulgular: Anaerop kültür için gönderilen 1630 klinik örnekten $41(\% 2,5)$ anaerop bakteri izole edilmiştir. Anaerop bakteri izole edilen örneklerin en çok Kadın Hastalıkları ve Doğum Kliniği (\%29) ve Kulak-Burun-Boğaz (\%29) kliniklerinden ve en fazla abse (\%49) örneklerinden izole edildiği belirlenmiştir. İzole edilen anaerop bakterilerin \%71'inin Gram-negatif, \%29'unun Gram-pozitif bakteriler olduğu, en sık izole edilen anaerop bakterilerin Bacteroides fragilis grubu (\%24) ve Prevotella cinsi (\%22) bakteriler olduğu bulunmuştur. Klindamisin direncinin oldukça yüksek olduğu, anaerop Gram-negatif çomaklarda karbapenem direncinin olmadığı, ancak suşların üçte birinin amoksisilin+klavulanik asite dirençli olduğu bulunmuştur.

Corresponding author/iletişim kurulacak yazar: oksuz|@istanbul.edu.tr

Submitted/Başvuru: 09.09.2019 • Revision Requested/Revizyon Talebi: 14.04.2020 •

Last Revision Received/Son Revizyon: 14.04.2020 • Accepted/Kabul: 16.06.2020 • Published Online/Online Yayın: 05.10.2020

(C) Telif Hakkı $2020 \mathrm{~J}$ Ist Faculty Med - Makale metnine jmed.istanbul.edu.tr web sayfasından ulaşılabilir.

(C) Copyright 2020 by J Ist Faculty Med - Available online at jmed.istanbul.edu.tr 
were resistant to clindamycin and about a third of amoxicillin+ clavulanate. Increased resistance to these antibiotics used empirically in the treatment of infections caused by anaerobic Gram-negative rods is anticipated to limit antibiotic treatment regimens in the future. Routine monitoring of resistance is necessary for proper empirical treatment.

Keywords: Anaerobic bacteria, antibiotic resistance
Sonuç: Özellikle B. fragilis grubunda olmak üzere, izole edilen anaerop Gram-negatif çomakların yarısından fazlasının klindamisine ve yaklaşık üçte birinin amoksisilin+klavulanata dirençli olması dikkat çekicidir. Ampirik olarak kullanılan antibiyotiklere karşı artan direncin, gelecekteki antibiyotik tedavi rejimlerini kısıtlayacağı tahmin edilmektedir. Uygun ampirik tedavi için direncin rutin olarak izlenmesi gereklidir.

Anahtar Kelimeler: Anaerop bakteri, antibiyotik direnci

\section{INTRODUCTION}

Anaerobic bacteria, which are located in the majority of body surfaces and in the mucous membranes, are the important members of the human normal microbiota. These bacteria are mainly found on the skin, mouth, gastrointestinal system, and female genital system. Anaerobic bacteria cause endogenous infections when they increase in number in the region where they are found as normal microbiota or when they reach the sterile regions, and exogenous infections by entering into the body by accidents or traumas. Anaerobic bacteria may cause various infections in the sterile regions, such as wound infections, bacteremia, osteomyelitis, intra-abdominal infections, endophthalmitis, gas gangrene, or tooth and mouth infections, when the host's defense is weakened. They generally cause polymicrobial infections together with aerobic bacteria (1-3).

Treatment of polymicrobial anaerobic infections is generally performed by antibiotic treatment together with surgical drainage. Because most anaerobic infections are mixed infections, so antibiotics which are effective for both aerobic and anaerobic organisms must be used in treatment. Although clindamycin and metronidazole are known as the most effective drugs in the treatment of anaerobic infections, resistance to these drugs has developed in recent years. The alternative options are cefoxitin, beta lactam-beta lactamase inhibitors, carbapenems, and tigecycline $(4,5)$.

Identification of anaerobic bacteria and antibiotic susceptibility testing cannot be performed in most microbiology laboratories due to various reasons including technical difficulties, and empirical treatment of anaerobic infections were based on the susceptibility pattern reports of various research (6). Researchers have recently reported that antibiotic resistance is increasing rapidly in anaerobic bacteria as well as in aerobic bacteria $(6,7)$. In this study we aimed to identify the anaerobic bacteria isolated from clinical samples in 2018, to determine the resistance of anaerobic Gram-negative rods to antibiotics, and to compare our findings the susceptibility results of anaerobic Gram-negative rods isolated in the same unit between 2015 and 2017.

\section{MATERIAL AND METHOD}

We evaluated the anaerobic bacteria isolated from various samples (abscess, tissue, pleural fluid, peritoneal fluid, etc.) in our laboratory in 2018 and the resistance of anaerobic Gram-negative rods to antibiotics, then we compared with the data of the anaerobic bacteria isolated between 2015-2017 in the same unit. For the anaerobic culture, the samples were inoculated on $5 \%$ sheep blood Schaedler agar and cooked meat broth (Beckton Dickinson, USA), and were incubated for $48-72 \mathrm{~h}$ at $37^{\circ} \mathrm{C}$ in an anaerobic jar with an anaerobic environment provider (GasPak, Oxoid, UK). Following an aerotolerance test at the end of the incubation period, the colonies reproducing in only anaerobic environments were identified as anaerobic bacteria. Identification of anaerobic bacteria was performed with colony morphology, conventional tests, and using the anaerobic diagnostic discs (An-Ident-disk, Oxoid, UK) including kanamycin (1000 $\mu \mathrm{g})$, colistin (10 $\mu \mathrm{g})$, vancomycin $(5 \mu \mathrm{g})$, penicillin $(2 \mathrm{IU})$, erythromycin (60 $\mu \mathrm{g})$, rifampicin $(15 \mu \mathrm{g})$. Identifications were evaluated according to the recommendations of the manufacturing company and to scientific reference books (8). Bacterial suspensions were adjusted to $1 \mathrm{McF}$ arland turbidity for antibiotic susceptibility tests and performed with a gradient test ( $E$ test, bioMerieux, France) on 5\% sheep blood Brucella agar including hemin $(5 \mu \mathrm{g} / \mathrm{mL})$, and Vitamin $\mathrm{K} 1$ $(1 \mu \mathrm{g} / \mathrm{mL})$, for amoxicillin + clavulanate, imipenem, cefoxitin, metronidazole, and clindamycin. Antibiotic susceptibility test results were evaluated according to Clinical \& Laboratory Standards Institute(CLSI) criteria and the recommendations of the manufacturing company $(9,10,38)$.

\section{RESULTS}

Forty-one anaerobic bacteria were isolated in 35 out of 1630 clinical samples $(2.5 \%)$ sent for anaerobic culture to our laboratory in 2018. We found that the anaerobic bacteria isolated samples were mostly submitted from Gynecology and Obstetrics Clinic (29\%), and Otorhinolaryngology (29\%) clinics, and the most of anaerobic bacteria were isolated from abscess (49\%) samples. Seventy-one percent of the anaerobic bacteria isolated were Gram-negative bacteria, and 29\% were Gram-positive, and most frequently isolated anaerobic bacteria were 
Bacteroides fragilis group (24\%), and Prevotella species (22\%) (Table 1).

A total of $223(4 \%)$ anaerobic bacteria were isolated from $143(2.5 \%)$ clinical samples $(n=5535)$ sent for anaerobic culture in a three-year period between 2015-2017 (11). One hundred sixty-one (72\%) of these anaerobic bacteria were isolated from abscess, biopsy and tissue samples, $46(21 \%)$ were isolated from sterile body fluids, and 16 (7\%) were isolated from blood samples in a three-year period. Eighty percent of patients from whom anaerobic bacteria were isolated from their clinical samples were adults. A total of 223 anaerobic bacteria consisting of 152 (68\%) Gram-negative, and 71 (32\%) Gram-positive (35 anaerobic Gram-positive cocci, 36 anaerobic Gram-positive rod) were isolated from the clinical samples of a total of 143 patients. Twelve of the anaerobic Gram-positive rods were identified as Cutibacterium acnes, five were Actinomyces spp, and three were identified as Clostridium spp. (Table 1). Table 2 shows the antibiotic resistance rates of anaerobic Gram-negative rods isolated between 20152017, and in 2018.

\section{DISCUSSION}

Antimicrobial resistance has significantly increased in most pathogenic anaerobic bacteria in the last 20-30 years. However, antibiotic susceptibility tests for anaerobic bacteria cannot always be performed in most microbiology laboratories, owing to difficulties in the isolation of the anaerobic bacteria, lack of a standardised susceptibility methods, lack of correlation between the susceptibility test results and the clinical response. As a result of these, the antimicrobial resistance issue has usually been ignored by the clinicians and microbiologists due to necessity of immediate initiation of the empirical treatment $(3,12,13)$.

Obtaining data about the antibiotic susceptibility of anaerobic bacteria is highly important for clinical laboratories because the treatment of anaerobic infections is usually performed empirically in the guidance of the studies reporting susceptibility patterns (6). An increase in morbidity, mortality, and hospitalization period occurs if initial antibiotic treatment is not appropriate in severe infections associated with anaerobic bacteria $(3,12)$.

The Clinical and Laboratory Standards Institute (CLSI) does not recommend the performing of routine antibiotic susceptibility testing in anaerobic bacteria, owing to difficulties in susceptibility testings of anaerobic bacteria. It recommends the performing of antibiotic susceptibility testing in several conditions: in severe and life-threatening infections (bacteremia, endocarditis, brain abscess), for isolates of the resistant species, for anaerobic bacteria isolated from the sterile regions, in unresponsiveness to empirical treatment, in cases that require long term treatment, and in the isolation of high virulent bacteria (Bacteroides spp, Prevotella spp, and Fusobacterium spp) $(9,14)$. Researchers reported that routine susceptibility tests were not performed because the anaerobic Gram-positive cocci were generally sensitive to most of the antibiotics (15). However, resistance to penicillin and clindamycin has been reported as prevalent in anaerobic Gram-positive cocci in recent years, and the most effec-

Table 1: Isolated anaerobic bacteria in the period 2015-2017 and in 2018.

\section{Isolated anaerobic bacteria}

Bacteroides fragilis group

Porphyromonas spp.

Prevotella spp.

Fusobacterium spp.

Other anaerobic Gram-negative rods

Anaerobic Gram-negative cocci

Peptococus niger

Other anaerobic Gram-positive cocci

Cutibacterium acnes

Clostridium spp.

Actinomyces spp.

Eubacterium spp.

Other anaerobic Gram-positive rods
2015-2017

n (\%)

$60(26.9)$

37 (16.6)

$36(16.1)$

$16(7.2)$

$3(1.3)$

$-$

$1(0.4)$

34 (15.2)

$11(4.9)$

$3(1.3)$

$5(2.2)$

$1(0.4)$

$16(7.2)$

$223(100)$
2018

n (\%)

$10(24.4)$

$4(9.8)$

9 (22)

1 (2.4)

$4(9.8)$

1 (2.4)

$4(9.8)$

2 (4.8)

1 (2.4)

5 (12.2) 
Table 2: Resistance to antibiotics by years in isolated anaerobic Gram-negative rods (\%).

\begin{tabular}{|c|c|c|c|c|}
\hline \multirow{2}{*}{$\begin{array}{l}\text { Bacteria/Antibiotics } \\
\text { Bacteroides fragilis group }\end{array}$} & \multicolumn{4}{|c|}{ Years } \\
\hline & 2015 & 2016 & 2017 & 2018 \\
\hline Amoxicillin+Clavulanate & 18 & 18 & 21.4 & 30 \\
\hline İmipenem & 0 & 4 & 0 & 0 \\
\hline Cefoxitin & 33 & - & 46 & 10 \\
\hline Clindamycin & 75 & 47 & 50 & 87 \\
\hline Metronidazole & 6.2 & 9.5 & - & - \\
\hline \multicolumn{5}{|l|}{ Fusobacterium spp. } \\
\hline Amoxicillin+Clavulanate & 20 & 5.8 & 33.3 & - \\
\hline İmipenem & 0 & 0 & 0 & - \\
\hline Cefoxitin & 0 & 0 & 0 & - \\
\hline Clindamycin & 44.4 & 38 & 16.6 & - \\
\hline Metronidazole & 25 & 25 & 20 & - \\
\hline \multicolumn{5}{|l|}{ Porphyromonas spp. } \\
\hline Amoxicillin+Clavulanate & 11.1 & 0 & 0 & 33 \\
\hline İmipenem & 12.5 & 0 & 0 & 0 \\
\hline Cefoxitin & 0 & 0 & 0 & 66 \\
\hline Clindamycin & 83,3 & 44.4 & 37.5 & 66 \\
\hline Metronidazole & 11.1 & 28.5 & 0 & - \\
\hline \multicolumn{5}{|l|}{ Prevotella spp. } \\
\hline Amoxicillin+Clavulanate & 20 & 0 & 0 & 33 \\
\hline İmipenem & 0 & 0 & 0 & 0 \\
\hline Cefoxitin & 0 & 0 & 0 & 0 \\
\hline Clindamycin & 40 & 33.3 & 66.6 & 28 \\
\hline
\end{tabular}

tive antibiotics in anaerobic Gram-positive rods were reported as penicillin, and carbapenems (16).

The basic approach in the management of severe anaerobic infections is antibiotic treatment combined with surgical intervention. As Bacteroides species constitute a significant part of normal microbiota, control of the disease is highly difficult in infections resulting from the endogenous dissemination of this organism. Antibiotic prophylaxis might be required when these organisms reach sterile regions, as a consequence of the deterioration of the natural barriers of mucosal surfaces with medical procedures. Almost all members of the $B$. fragilis group, many Prevotella and Porphyromonas species, and some Fusobacterium isolates produce the B-lactamase enzyme which provides resistance to penicillin, and cephalosporins. Moreover plasmid-mediated resistance to clindamycin is common. Therefore the most effective antibiotics for Gram-negative anaerobic rods are metronidazole, carbapenems, and B-lactam- B-lactamase inhibitors (14,
17). Data concerning the resistance of anaerobic bacteria are limited to studies from reference laboratories or international large companies, except the surveillance studies in hospitals with good facilities, because in many centers susceptibility tests for anaerobic bacteria are rarely performed. Although there are differences between the regions, cities, and centers, in the studies performed in countries with approved methods, common tendencies may be detected, and tendencies affecting the empirical antibiotic treatment recommendations occur. The antibiotic susceptibility of these agents cannot be guessed before testing because there is inadequate local or national data for estimating the susceptibility due to the increased resistance against clindamycin, and cefoxitin, particularly in $B$. fragilis group $(13,14)$. Anaerobic bacteria had a standard susceptibility pattern 30 years ago, however, the efficacy of selected empirical treatment currently cannot be anticipated. It is known that the clinicians generally do not have adequate time for waiting for the results of antibiotic susceptibility testing in anaerobic infections. The 
surveillance reports from Europe and the United States of America (USA) showed that resistance against all classes of antimicrobial agents has consistently been increasing, and even some antibiotics are not effective at all (14). In the paragraphs below, the resistance rates to antibiotics of anaerobic bacteria isolated in our study are compared with similar studies in the literature.

Metronidazole (5-nitroimidazole) is the first drug option, which is highly effective for anaerobes. Although the drug has been used since the 1960s, the resistance is rare, though metronidazole resistant $B$. fragilis isolates have recently been reported in 1-8\% from different regions of the world $(3,13)$. Metronidazole resistance is associated with the nim genes which encode the production of a different nitroreductase enzyme. Nim genes were suggested to encode various homologous nitro imidazole reductases that can directly convert 5-nitroimidazole to inactive 5-aminoimidazole, and thus prevent the reduction of metronidazole to active nitro radical anion form (24). 5-nitroimidazole is a prodrug, and must be reduced by the intracellular transport protein ferredoxin after entry into the cell for its activation. Nitroimidazole reductases encoded by nim genes probably compete with this reduction, and convert the nitro group of the prodrug to an amin derivative that is not toxic for the bacteria (13). While nine different nim genes (A-I) have been identified so far, metronidazole resistance was also reported in isolates that did not have the nim gene (3). Resistance not associated with the nim gene was reported in a patient with a history of excessive use of metronidazole, though its mechanism is not completely known (13). The metronidazole resistance gene is found both on the chromosome and plasmid, and most of them are transferable (10). Metronidazole resistance was detected in 6-9\% of the $B$. fragilis group, in 20-25\%, of Porphyromonas species, in $11-28 \%$ of Prevotella species, and in $0-33 \%$ of Fusobacterium species of the anaerobic Gram-negative rods isolated in our hospital between 2015-2018 (Table 2). The investigation of similar studies in our country showed that Bahar et al., reported to have found no metronidazole resistant isolates in $B$. fragilis, Porphyromonas and Prevotella isolates $(18,19)$. Kiremitçi et al. reported only $18 \%$ in all anaerobic bacteria, and found the resistance to metronidazole in only one $B$. fragilis isolate (20). Ülger Toprak et al. (21), found no metronidazole resistance in their study investigating the carbapenem and metronidazole resistance in $66 \mathrm{~B}$. fragilis isolates. These researchers found that all isolates were susceptible to metronidazole in their antimicrobial resistance study with 508 Prevotella isolates from 13 countries (22). Demir et al. found no metronidazole resistance in $B$. fragilis groups in their study (23). To detect a very small rate of resistance to metronidazole or no metronidazole resistance in similar studies conducted in our country shows the significance of the metronidazole resistance of $6 \%$ and $9 \%$ detected in
2015 and 2016 in our study. The priority usage of metronidazole for empirical treatment in surgical clinics in our hospital may explain the higher metronidazole resistance rates detected in all Gram-negative rods. A study from South Africa reported that $8 \%$ of $23 \mathrm{~B}$. fragilis isolates were highly resistant to metronidazole $(>256 \mu \mathrm{g} / \mathrm{mL})$. Researchers reported that only nim genes could not be blamed for resistance due to metronidazole highly resistant isolates having no nim gene (24). Syndman et al., reported to have detected metronidazole resistance in two isolates in their study conducted with 1957 B. fragilis groups isolated from eight centers in a period of fouryears (25). Researchers reported that only one isolate was resistant to metronidazole in a seven-year surveillance study with $5,225 \mathrm{~B}$. fragilis isolates from 10 centers in the USA (6).

Increased resistance rates to clindamycin, which is the classic anaerobic effective drug, have been reported in the last 20 years. The rates of resistance are 10-60\% in Bacteroides species but it varies between countries. The resistance mechanism of clindamycin is known as the target change after methylation of $23 \mathrm{~S}$ rRNAs. The clindamycin resistance gene is located on a transportable plasmid, which explains the rapid dissemination of clindamycin resistance (10). We found the resistance rates of clindamycin as $47-87 \%$ in Bacteroides spp, as $16-44 \%$ in Fusobacterium spp, $37-83 \%$ in Porphyromonas spp, and as $28-66 \%$ in Prevotella spp between $2015-2018$ in the present study (Table 2). Investigation of similar studies in our country showed that Bahar et al. reported to have found the clindamycin resistance as $5-10 \%$ in Prevotella spp, and found no clindamycin resistant isolate in Porphyromonas spp (19). Kiremitçi et al. reported the clindamycin resistance as $53 \%$ in $B$. fragilis isolates $(n=15)$ (20). Clindamycin resistance was reported as $36 \%$ in 45 $B$. fragilis group isolates in the study of Ülger Toprak et al. (26). Clindamycin resistance was detected as $28 \%$ in B. fragilis group, and as $11 \%$ in Prevotella species in the study of Demir et al. (23). Gürler et al., reported the clindamycin resistance in B. fragilis isolates as $16 \%(27)$, and Liu et al. reported resistance as 37\% (7). Clindamycin resistance was reported as $26 \%$ in a seven-year surveillance study with $5,225 \mathrm{~B}$. fragilis isolates from 10 centers in the USA (6). Ülger Toprak et al. reported the clindamycin resistance as 34\% in their antimicrobial resistance study with 508 Prevotella isolates from 13 countries. In addition, researchers emphasized that detection of antibiotic resistance against three or more antibiotics of $10 \%$ of Prevotella isolates was concerning (22). Mobile genetic elements were suggested to have a significant role in the dissemination of multiple resistance phenotypes in anaerobic bacteria (14). Syndman et al. (25), reported to have detected high resistance $(60 \%)$ for clindamycin in their study with 1957 B. fragilis group isolates isolated from eight centers in a four-year period. The rate of 
clindamycin resistance in our study are quite high, similar to the rates obtained both in our country and the other countries.

A different mechanism has been reported in the resistance against beta lactam-beta lactamase inhibitors. Beta lactam resistance develops when excessive cephalosporinase is produced, however the susceptibility to beta lactam-beta lactamase inhibitors remains. Resistance to beta lactam-beta lactamase inhibitor combinations may develop only in addition to another resistance mechanism such as porin loss (12). Researchers reported that the presence of cepA associated IS1124 increased the gene expression, resulting in excessive enzyme production, and the changes in porin proteins caused the resistance (28). Amoxicillin+clavulanate resistance in isolated anaerobic Gram-negative rods was detected as $18-30 \%$ in B. fragilis group, as 6-33\% in Porphyromonas species, as $11-33 \%$ in Prevotella species, and as 0-20\% in Fusobacterium species in our study (Table 2). These rates were higher than the results of other studies. It has been suggested that the rate of resistance increased due to frequency of use, because anaerobic bacteria generally causes polymicrobial infections. Beta lactam-beta lactamase inhibitors are also effective antibiotics for facultative anaerobic bacteria, which produce an extended spectrum beta-lactamase. Bahar et al. reported to have detected no resistant isolates against amoxicillin+clavulanate in B. Fragilis group isolates $(n=25)$ isolated from the abscess samples of pediatric patients in their study (18). Bahar et al. reported to have found no ampicillin +sulbactam resistance in Porphyromonas and Prevotella isolates in another study (19). Ülger Toprak et al. reported the amoxicillin+clavulanic acid resistance as $2 \%$ in $45 \mathrm{~B}$. fragilis group isolates in their study (26). Less than $10 \%$ resistance to beta lactam-beta lactamase inhibitors has been reported in studies from different countries $(4,13,29)$. Conversely, high resistance rates $(37 \%)$ for ampicillin +sulbactam were reported in $B$. fragilis isolates from a study reported from Taiwan (37). In addition, Liu et al. reported the amoxicillin+clavulanic acid resistance as $23 \%$ in $B$. fragilis isolates (7). These rates were similar with our results.

Carbapenems are generally stable against most carbapenemases, but resistant strains are rarely reported. Carbapenems and piperacillin+tazobactam were reported as the most active agents with resistance rates of $0.9 \%$, and $2.3 \%$ in $B$. fragilis isolates in a three-year surveillance study (30). Imipenem resistant $B$. fragilis isolates were first reported in Japan (31), later different studies also reported the imipenem resistance in B. fragilis isolates (25). Carbapenem resistance in the $B$. fragilis group depends on the production of $B$ class metallo beta lactamase, from one of the cfiA/ccrA genes, and confers resistance to all beta lactams including the beta lactamase inhibitor combinations (13). Imipenem resistance in Turkey was first reported in the B. fragilis group in 1999, and it was shown that the resistance increased from $2 \%$ to $10 \%$ in a five-year period $(21,32)$. However, in two different studies, Bahar et al. reported no imipenem resistance in B. fragilis, Prevotella, and Porphyromonas isolates (18, 19). Similarly, we detected no carbapenem resistance in 2015, 2017, and 2018. In the present study however, 4\% imipenem resistance was detected in $B$. fragilis group bacteria from 2016. Kiremitçi et al. detected imipenem resistance in one $(6.6 \%)$ of the $B$. fragilis isolates $(n=15)$ in their study investigating the susceptibility in anaerobic bacteria (20). Imipenem resistance was detected as $2 \%$ in 45 B. fragilis group isolates in the study of Ülger Toprak et al. (26). The same researchers reported that $27 \%$ of $66 \mathrm{~B}$. fragilis isolates had the cfiA gene, $32 \%$ had the IS1187 insertion sequence, and five isolates had both the cfiA gene, and IS1187 insertion sequence, and these isolates were reported to have resistance to carbapenems. Researchers indicated, in accordance with the results of this study, that the presence of the IS element was important in determining the high level of carbapenem resistance (21). All isolates were sensitive to carbapenems in the resistance study of the same researchers with 508 Prevotella isolates from 13 countries (22). No imipenem resistance was detected in $B$. fragilis group bacteria in the study of Demir et al. (23). Liu et al. reported an increase in carbapenem resistance of 207 B. fragilis strains isolated from the blood cultures between 2002-2006. The rates of non-susceptibility for imipenem and meropenem in $B$. fragilis isolates which were different than our study were indicated as $7 \%$, and $12 \%$, respectively (7). This rate was significantly high for carbapenems. Researchers in a study in South Africa reported that $8 \%$ of 23 B. fragilis isolates were highly resistant to imipenem $(>256 \mu \mathrm{g} / \mathrm{mL})$ (24). Carbapenem resistance was detected as approximately $1 \%$ in a seven-year surveillance study with 5225 B. fragilis isolates from 10 centers in the USA (6). Syndman et al., indicated that while the rate of carbapenem resistance was detected as $1.1-2.5 \%$ in 1957 B. fragilis group isolates isolated from eight centers in a four-year period, isolates with high MIC for carbapenems had no cfiA gene (25). In a study performed using the agar dilution method with anaerobic bacteria isolated from 521 clinic samples between 2014-2016 in South Korea, imipenem resistance was detected in $5 \%$ of $B$. fragilis strains, and as $14 \%$ in other Bacteriodes strains (33). Recently, detection of resistance to carbapenems, the most wide-spectrum antibiotic, in anaerobic Gram-negative rods might be the indicator of an alarming condition.

Cefoxitin is in group $\mathrm{C}$ among antibiotics recommended by $\mathrm{CLSI}$ for anaerobic bacteria and is recommended as an alternative in strains that are resistant to most primary drugs (9). In addition, cefoxitin is not recommended for intra-abdominal infections caused by Bacteroides species (3). Beta lactamase gene encoded by cepA and cfxA, 
which may be transferred by plasmid or a mobile transposon, is responsible from the resistance of cefoxitin (13), and most $B$. fragilis isolates and two-thirds of Prevotella species are known to produce beta lactamase (7). The rate of resistance to cefoxitin in Bacteroides species was found as $10-33 \%$, as $0-66 \%$ in Porphyromonas species, and no cefoxitin resistance was detected in Fusobacterium and Prevotella species in current study. Bahar et al. reported the cefoxitin resistance as $32 \%$ in the $B$. fragilis group isolated from the abscess samples of pediatric patients $(n=25)$ in compliance with the results of this study (18). The same researchers reported the cefoxitin resistance as 3\% in Porphyromonas isolates (19). Kiremitçi et al. reported the cefoxitin resistance as $7 \%$ in $B$. fragilis isolates $(n=15)(20)$. Ülger Toprak et al. in a study reported the cefoxitin resistance as $11 \%$ in 45 B. fragilis group isolates (26). Demir et al. found the cefoxitin resistance as $36 \%$ in the B. fragilis group, and as $11 \%$ in Prevotella species (23). Gürler et al. found the cefoxitin resistance as $16 \%$ in B. fragilis isolates (27). Researchers reported in a study conducted in South Africa that $8 \%$ of 23 B. fragilis isolates were highly resistant to cefoxitin ( $>256 \mu \mathrm{gg} /$ $\mathrm{mL}$ ) (24). Cefoxitin resistance was reported as $10 \%$ in a seven-year surveillance study performed with 5225 B. fragilis isolates from ten centers in the USA (6). Cefoxitin resistance was detected as $7 \%$ in compliance with our results in 2018 (10\%), in accordance with susceptibility results performed using the agar dilution method in anaerobic bacteria isolated from 521 clinical samples in a study conducted between 2014-2016 in South Korea (33).
The resistance rate of cefoxitin is increasing in anaerobic Gram-negative bacilli with respect to rates in our country and in the world.

Investigation of studies associated with antibiotic susceptibility in anaerobic bacteria showed that most of the research was focused on the $B$. fragilis group, and antibiotic resistance has been gradually increasing. The resistance rates to antibiotics in the $B$. fragilis group indicated in various studies are given in Table 3. The most comprehensive study associated with the antimicrobial resistance of $B$. fragilis group was the study of Nagy et al., which included 824 isolates from 13 European countries (34). Researchers indicated that the significant increase in antibiotic resistance was detected for cefoxitin, clindamycin, and moxifloxacin, and total resistance to cefoxitin was reported as $17 \%$, resistance to clindamycin as $32 \%$, resistance to moxifloxacin as $13 \%$, resistance to amoxicillin+clavulanic acid as $3 \%$, resistance to piperacillin+tazobactam as $10 \%$, resistance to imipenem as $1.2 \%$, and resistance to metronidazole was reported as less than $1 \%$. Researchers emphasized that isolates which were not sensitive to imipenem and metronidazole were more resistant to the other antibiotics. Piperacillin+tazobactam was reported to be more active compared with amoxicillin+clavulanic acid. Antibiotic resistance was reported to differ between the regions; resistance to moxifloxacin $(21 \%)$ in Scandinavian countries, and resistance to metronidazole (42\%) in Mediterranean countries were reported to be higher. As Turkey is in the Mediterranean region,

Table 3: Antibiotic resistance rates in B. fragilis group isolates in various studies in the literature (\%).

\begin{tabular}{lccccc}
\hline Research & Amox+Clavulanate & Imipenem & Cefoxitin & Clindamycin & Metronidazole \\
Gurler 1997 & 0 & 0 & 16 & 16 & 0 \\
Bahar 2002 & 0 & 0 & 32 & 0 & 0 \\
Ulger 2004 & 2 & 2 & 11 & 36 & 0 \\
Syndman 2007 & - & 1 & 10 & 25 & 1 isolate \\
Kiremitci 2008 & - & 1 isolate & 7 & 53 & 1 isolate \\
Liu 2008 & 23 & $7-12$ & 13 & 37 & 0 \\
Syndman 2010 & & 0,9 & & & \\
Bouchillon 2010 & - & $0-5$ & $10-27$ & $10-29$ & $0-1.2$ \\
Galvao 2011 & - & 8 & 8 & 0 & 8 \\
Nagy 2011 & 10 & 1.2 & 17 & 32 & $<1$ \\
Syndman 2011 & & $1.1-2.5$ & 7 & 30 & 2 isolate \\
Ulger 2012 & - & 1,5 & - & - & 0 \\
Demir 2018 & - & 0 & 36 & 28 & 0 \\
Rodloff 2018 & - & 1.7 & - & 22 & 0.5 \\
Oksuz 2018 & 17.8 & 2 & 17.4 & 54 & 4.6 \\
Present study & 30 & 0 & 10 & 87 & - \\
\hline
\end{tabular}


this result shows that our results were compatible with the rates of Nagy. Piperacillin+tazobactam resistance was also found to be higher in Scandinavian countries. When the researchers compared the data of two multi-center studies (15 countries with 1289 isolates, and 19 countries with 1,284 isolates) conducted in Europe in previous years with their own studies, they pointed out that resistance has increased over the years.

In accordance with the results of "The Tigecycline European Surveillance Trial (TEST)" presented in 2010 in the European Congress of Clinical Microbiology and Infectious Diseases (ECCMID), resistance to cefoxitin was reported as $10-27 \%$, to clindamyc in as $10-29 \%$, to metronidazole as $0-1.2 \%$, to meropenem as $0-5 \%$, and to piperacillin+tazobactam as $0-12 \%$ in 1420 B. fragilis isolates (35). Antimicrobial resistance was investigated in 7008 anaerobic bacteria in the TEST study conducted in 2018, and most of the anaerobic bacteria were reported to be susceptible to meropenem, metronidazole, and tigecycline, but resistance to clindamycin in Gram-negative bacteria (28-48\%) was alarming (36). In addition, in the TEST study, $22 \%$ of the strains were shown to be resistant to clindamycin, $1.7 \%$ to meropenem, and 0.5\% to metronidazole in $B$. fragilis isolates; however, clindamycin resistance was between $10-30 \%$, meropenem resistance $0.2-0.6 \%$, and metronidazole resistance $0.6-1.9 \%$ in Prevotella species (36). The data of this recent study were similar to our results and highlight the increase in carbapenem resistance.

One of the limitations of our study was that full identification could not be performed for all isolated anaerobic bacteria due to financial issues, and antibiotic resistance of anaerobic Gram-positive bacteria could not be investigated. In addition, metronidazole resistance could not be investigated in anaerobic Gram-negative rods in 2018 due to the same financial issues. Although the number of anaerobic bacteria isolated is low, it can be said that the resistance rates obtained in 2018 are still high, and the high resistance rates for clindamycin in particular could not be ignored. Another limitation of our study was that susceptibility tests could not be performed using the gold standard method of agar dilution due to the study consisting of retrospective data. Unfortunately, this method requires intensive labour, and could not be performed during routine laboratory workflow. Researchers in a study in Switzerland reported that a concentration gradient test was compatible with the agar dilution test, and the rate of major and very major error was less than $1 \%$ (37). Furthermore, in a study which compared the agar dilution, disk elucion in broth, and gradient test methods for susceptibility tests of anaerobic bacteria $(n=86)$ in our department, no statistically significant difference between three methods was reported (11). In addition, the rate of production of beta lactamase could not be de- termined in our study. Whether or not to use beta lactam antibiotic in treatment in centers where no routine antibiotic susceptibility tests are performed is determined by detecting the presence of beta lactamase in anaerobic bacteria. We did not perform a beta lactamase test in our study because many anaerobic Gram-negative rods, primarily the $B$. fragilis, are known to produce high rates of beta lactamase. We performed antibiotic susceptibility tests for all pathogenic anaerobic bacteria isolated. In addition, mechanisms other than the beta lactamase production may also develop resistance to antibiotics in anaerobic Gram-negative rods. Anaerobic bacteria without beta-lactamase enzyme, but resistant to ampicillin, have been reported rarely. We suggest that all these limitations may be eliminated with well planned prospective studies using the gold standard methods.

\section{CONCLUSION}

It was striking to find out in our study that more than half of the anaerobic Gram-negative rods primarily the $B$. fragilis group were resistant to clindamycin, and approximately one third were resistant to amoxicillin+clavulanate. It is estimated that the increased resistance to these antibiotics, which are empirically used in the treatment of anaerobic Gram-negative rods associated infections will limit the antibiotic treatment regimes in the future. The routine monitoring of resistance is highly important for providing appropriate empirical treatment.

Acknowledgments: I would like to thank my Professor Dr. Nezahat GÜRLER who has supported me in my interest in anaerobic bacteria since I first was introduced to microbiology, to Masters student Rama Al Hamwi, who compiling the isolated anaerobic bacteria in 2018, and to Prof. Dr. Arif KAYGUSUZ for his contributions in the post reading of the article.

Ethics Committee Approval: Ethics committee approval was not received due to the retrospective nature of the study

Informed Consent: Informed consent was not received due to the retrospective nature of the study.

Peer Review: Externally peer-reviewed.

Author Contributions: Conception/Design of Study- L.Ö.; Data Acquisition- L.Ö.; Data Analysis/Interpretation- L.Ö.; Drafting Manuscript- L.Ö.; Critical Revision of Manuscript- L.Ö.; Final Approval and Accountability- L.Ö.

Conflict of Interest: Authors declared no conflict of interest.

Financial Disclosure: Authors declared no financial support.

Teşekkür: Mikrobiyolojiyle ilk tanışmamdan bu yana anaerobik bakterilere olan ilgimde beni destekleyen Prof. Dr. Nezahat Gürler'e, 2018 yılında izole anaerobik bakterilerin derlenmesindeki 
katkılarından dolayı Yüksek lisans öğrencisi Rama Al Hamwi'ye ve Prof. Dr. Arif KAYGUSUZ'a makalenin son okumasındaki katkılarından dolayı teşekkür ederim.

Etik Komite Onayı: Retrospektif çalışma olduğundan etik komite onayı alınmamıştır.

Bilgilendirilmiş Onam: Retrospektif bir çalışma olduğundan bilgilendirilmiş onam alınmamıştır

Hakem Değerlendirmesi: Dış bağımsız.

Yazar Katkıları: Çalışma Konsepti/Tasarım- L.Ö.; Veri ToplamaL.Ö.; Veri Analizi/Yorumlama- L.Ö.; Yazı Taslağı- L.Ö.; İçeriğin Eleştirel Incelemesi- L.Ö.; Son Onay ve Sorumluluk- L.Ö.

Çıkar Çatışması: Yazarlar çıkar çatışması beyan etmemişlerdir.

Finansal Destek: Yazarlar finansal destek beyan etmemişlerdir.

\section{REFERENCES}

1. Baysallar M, Bedir O. Anaerobic Bacteriology. In: Garcia LS, Isenberg HD, editors. The Handbook of Clinical Microbiology Methoods (Translate eds: Başustaoğlu A, Yıldıran ŞT). ASM Press: Washington; 2014, s. 4.0.1.

2. Jousimies-Somer HR, Summanen $P$, Citron DM, Baron EJ, Wexler HM, Finegold SM, editors. Waddsworth-KTL Anaerobic Bacteriology Manual. Chapter 1: Introduction to Anaerobic Bacteriology. Star Publishing Company: California; 2002, p.1.

3. Tunçkanat F. Anaerobic bacteria: General characteristics. In: Topçu AW, Söyletir G, Doğanay M, editors. Infectious Diseases and Microbiology. Nobel Medical Bookstores: İstanbul; 2017, s.2036.

4. Cohen-Poradosu R, Kasper DL. Anaerobic Infections: General concepts. In: Bennett JE, Dolin R, Blaser MJ editors. Mandell, Douglas, and Bennett's Principles and Practice of Infectious Diseases. Elseiver: USA; 2015, s.2736-43.

5. Yenen OS. Infections of anaerobic bacteria. In: Brooks GF, Carroll KC, Butel JS, Morse SA, Mietzner TA, editors. Jawetz, Melnick, Adelberg Medical Microbiology. Nobel Medical Bookstores: İstanbul; 2014, s.295.

6. Syndman Dr, Jacobus NV, Mc Dermott LA, Ruthazer R, Golan Y, Goldstein EJ, et al. National Survey on the Susceptibility of Bacteroides fragilis Group: Report and Analysis of Trends in the United States from 1997 to 2004. Antimicrob Agents Chemother 2007;51(5):1649-55. [CrossRef]

7. Liu CY, Huang YT, Liao CH, Yen LC, Lin HY, Hsueh PR. Increasing Trends in Antimicrobial Resistance among Clinically Important Anaerobes and Bacteroides fragilis Isolates Causing Nosocomial Infections: Emerging Resistance to Carbapenems. Antimicrob Agents Chemother 2008;52(9):3161-8. [CrossRef]

8. Procop GW, Church DL, Hall GS, William M. Janda WM, Koneman EW, Schreckenberger PC, Woods GL, editors. Koneman's Color Atlas \& Textbook of Diagnstic Microbiology. The anaerobic bacteria. Lipincott Williams \& Wilkins: Philadelphia; 2017, p.983-1071.

9. Clinical and Laboratory Standards Institute (CLSI). Performance Standards for Antimicrobial Susceptibility Testing. 27th ed. CLSI supplement M100, 2017. S-26.
10. Jousimies-Somer HR, Summanen P, Citron DM, Baron EJ, Wexler HM, Finegold SM, editors. Waddsworth-KTL Anaerobic Bacteriology Manual. Chapter 8. Susceptibility testing of anaerobic bacteria. Star Publishing Company: California; 2002, s.143.

11. Öksüz L, Gürler N. Resistance of anaerobic bacteria isolated from clinical specimens to antibiotics: A three-year surveillance. 33. Antimicrobial Chemothearpy Congress, Oral presentation, S130, 2-6 May 2018, Fethiye.

12. Dubreuil L, Odou MF. Anaerobic bacteria and antibiotics: What kind of unexpected resistance could I find in my laboratory tomorrow? Anaerobe 2010;16:555-9. [CrossRef]

13. Hecth DW. Anaerobes: Antibiotic resistance, clinical significance, and the role of susceptibility testing. Anaerobe 2006;12:115-21. [CrossRef]

14. Gajdacs M, Spengler G, Urban E. Identification and Antimicrobial Susceptibility Testing of Anaerobic Bacteria: Rubik's Cube of Clinical Microbiology? Antibiotics 2017;6:129. [CrossRef]

15. Gürler N. Anaerobic cocci. In: Topçu AW, Söyletir G, Doğanay M. Infectious Diseases and Microbiology. s. 2046. Nobel Medical Bookstores: İstanbul; 2017.

16. Könönen E, editor. Anaerobic cocci and anaerobic Grampositive nonsporulating bacilli. In: Bennett JE, Dolin R, Blaser MJ. Mandell, Douglas, and Bennett's Principles and Practice of Infectious Diseases. Elseiver: USA; 2015, s.2781-6.

17. Murray PR, Rosenthal KS, Pfaller MA, editors. Medical Microbiology. Philadephia; 2009, s.399-404.

18. Bahar $H$, Mamal Torun $M$, Demirci $M$, Sever $N$, i̇stanbullu A. Anaerobic bacteria isolated from clinical specimens of pediatric patients and resistance to antibiotics. ANKEM Derg 2002;16(4):486-91.

19. Bahar H, Mamal Torun M, Demirci M, Kocazeybek B. Antimicrobial resistance and beta lactam production of clinical isolates of Prevotella and Porphyromonas species. Chemotherapy 2005;51:9-14. [CrossRef]

20. Kiremitçi A, Türkkan AA, Akgün Y, Durmaz G, Kaşifoğlu $\mathrm{N}$. Isolation of anaerobic bacteria from clinical samples and determination of antibiotic susceptibility. Bulletin of ANKEM 2008;22(3):132-44.

21. Ülger Toprak N, Uzunkaya ÖD, Soki J, Söyletir G. Susceptibility profiles and resistance genes for carbapenems (cfiA) and metronidazole (nim) among Bacteroides species in a Turkish University Hospital. Anaerobe 2012;18:169-71. [CrossRef]

22. Ulger Toprak N, Veloo ACM, Urban E, et al. A multicenter survey of antimicrobial susceptibility of Prevotella species as determined by E test methodology. Anaerobe 2018;52:915. [CrossRef]

23. Demir C, Keşli R. Identification of Anaerobic GramNegative Bacilli Isolated from Various Clinical Specimens and Determination of Antibiotic Resistance Profiles with E-Test Methods. Mikrobiyol Bul 2018;52(1):72-9. [CrossRef]

24. Galvao BPGV, Meggersee RL, Abratt VR. Antibiotic resistance and adhesion potential of Bacteroides fragilis clinical isolates from Cape Town, South Africa. Anaerobe 2011;17:142-6. [CrossRef]

25. Syndman DR, Jacobus NV, Mc Dermott LA, Golan Y, Goldstein EJ, Harrel L, et al. Update on resistance of Bacteroides fragilis group and related species with special attention to carbapenems 2006-2009. Anaerobe 2011;17:147-51. [CrossRef] 
26. Ülger Toprak N, Çelik C, Çakıcı Ö, Söyletir G. Antimicrobial susceptibilities of Bacteroides fragilis and Bacteroides thetaiotamicron strains isolated from clinical specimens and human intestinal microbiota. Anaerobe 2004;10(5):2559. [CrossRef]

27. Gürler N, Zandi H, Töreci K. Comparison of agar dilution, $\mathrm{E}$ test and broth disc elution methods in determining the susceptibility of anaerobic bacteria. Bulletin of ANKEM 1997; 11(4):487-92.

28. Tunçkanat F. Susceptibility tests of anaerobic bacteria and resistance status. Alıntılama tarihi: 09.07.2018. Available from: http://www.tmc-online.org/userfiles/file/AKG_ Sunumlar/22nisan/ferda_tunckanat_anaerop_bakterilerin_ duyarlilik_testleri.pdf.

29. Garrett WS, Onderdonk AB. Bacteroides, Prevotella, Porphyromonas, and Fusobacterium Species (and Other Medically Important Anaerobic Gram-Negative Bacilli). In: Bennett JE, Dolin R, Blaser MJ, editors. Mandell, Douglas, and Bennett's Principles and Practice of Infectious Diseases. Elseiver: USA; 2015, s.2773-80.

30. Syndman DR, Jacobus NV, McDermott LA, Golan Y, Hecht DW, Goldstein EJ, et al. Lessons Learned from the Anaerobe Survey: Historical Perspective and Review of the Most Recent Data (2005-2007) Clin Infect Dis 2010;50(Suppl 1):S26-33. [CrossRef]

31. Yamazoe K, Kato N, Kato $H$, et al. Distribution of the cfiA Gene among Bacteroides fragilis Strains in Japan and Relatedness of cfiA to Imipenem Resistance. Antimicrob Agent Chemother 1999;43(11):2808-10. [CrossRef]
32. Ülger Toprak N. Susceptibility tests and data Turkey: Anaerobes. Gülhane Microbiology Days, Antimicrobial Chemotherapy Laboratory Applications and Innovations. 20-22 Nisan 2010, İstanbul.

33. Byun BH, Kim M, Lee $Y$, Lee K, Chong Y. Antibiotic susceptibility patterns of anaerobic bacterial clinical isolates from 2014-2016, including recently named or renamed species. Ann Lab Med 2019;36:190-9. [CrossRef]

34. Nagy E, Urban E, Nord CE. Antimicrobial susceptibility of Bacteroides fragilis group isolates in Europe: 20 years of experience. Clin Microb Infect 2011;17:371-9. [CrossRef]

35. Bouchillon S, Renteria M, Hackel M, Johnson B, Dowzicky M. Gram-negative anaerobe susceptibility rates in six European countries, 2007-2009. 20th ECCMID Congress, P1293, Vienna, 10-13 April 2010.

36. Rodloff AC, Dowzicky MJ. In vitro activity of tigecycline and comparators against a European collection of anaerobes collected as part of the Tigecycline Evaluation and Surveillance Trial (T.E.S.T.) 2010-2016. Anaerobe 2018;51:7888. [CrossRef]

37. Wüst J, Hardegger U. Comparison of the $E$ test and a reference agar dilution method for susceptibility testing of anaerobic bacteria. Eur J Clin Microbiol Infect Dis 1992;11(12):1169-73. [CrossRef]

38. Biomerieux, E test application guide. 2012/07. Available from: https://www.biomerieux-usa.com/sites/subsidiary us/files/supplementary_inserts_-_16273_-_b_-_en_-_ eag_-_etest_application_guide-3.pdf Alıntılama tarihi: 15.05.2020. 